\title{
MIEJSCE NORWIDA W KULTURZE
}

Norwid daje odpowiedzi na aktualny kryzys postnowoczesności, choć nie sposób sprowadzić go do jednej teorii, jednej „narracji”, jednej syntezy. Norwid jest konstelacją, można śledzić jej gwiazdy, ich ewolucję i rewolucje, ich drogę mleczną i można tworzyć jej mapy. Ale nie sposób uchwycić jej jednym rzutem oka, by stwierdzić: rozumiem, znam, wiem. Ponieważ wymaga od czytelników nieustannej współpracy w znajdywaniu sensu, czyni z nich współautorów w „nieustannej dyskusji” prowadzonej przez społeczeństwo, przez cywilizacje różnych wieków, przez ludzi.

Choć jest obok Platona jednym z inspiratorów polskiej Konstytucji, odwołującej się do prawdy, sprawiedliwości, dobra i piękna ${ }^{1}$, które są w Promethidionie „profilami Bożymi" obrona Prawa podstawowego podzieliła Polaków w trakcie obecnej „wojny kulturowej” pomiędzy odwołujących się do oświeceniowego kultu Prawa i trójpodziału władzy oraz zwolenników romantycznego mesjanizmu narodowego z kultem cierpiętnictwa. W Promethidionie uderza uniwersalizm etyczny i otwarcie na wszystkich ludzi i kultury.

Ale to nie rozdarcie opinii społecznej jest przyczyną trudności z powstaniem monografii, o czym pisze Halkiewicz-Sojak ${ }^{2}$ - ze względu na trudności syntezy związanej z polifonią interpretacji rozmaitych studiów, często sprzecznych ze sobą, gdzie każde na swój sposób podchodzi do jego sztuki i stałego wpływu na poezję współczesną; ostatecznie ze względu na odrębność jego miejsca w kulturze, umykającego klasyfikacjom.

\footnotetext{
1 Tekst Preambuły z $1997 \mathrm{r}$.

${ }^{2}$ G. Halkiewicz-SoJAK, „Monografia Norwida - książka postulowana, ale czy możliwa?”, w: taż, Nawiązane ogniwo. Studia o poezji Cypriana Norwida i jej kontekstach, Toruń 2010, s. 15-24.
} 
Schematycznie można podzielić jego życie i dzieło na trzy części, odpowiadające arcydziełom: po okresie warszawskim i pobycie we Włoszech, gdzie w Rzymie w okresie wiosny ludów poznał Krasińskiego i Mickiewicza, powstał dialogowy poemat filozoficzny Promethidion, wydany w Paryżu 1851 r., uznany na początku XX w. - pół wieku później - za arcydzieło, źródło filozofii pracy - rozwiniętej później przez Józefa Tischnera i Jana Pawła II. Poprzez temat pracy i sztuki wiąże się wewnętrznie z Fortepianem Szopena (1865), ważnym również dla rozumienia wiary poety.

Drugi okres ma miejsce w Paryżu, gdzie mieszka od 1849 r., wiąże się przyjaźnią z Szopenem niebawem zmarłym, i gotów jest wstąpić do Kongregacji Zmartwychwstańców, ale ostatecznie nieprzyjęty, wyjeżdża do Ameryki w 1852 r. Powraca stamtąd do Londynu i znowu do Paryża w 1854 r. Pisze wówczas oryginalny poemat Quidam o końcu imperium rzymskiego (ukaże się dopiero w 1862 r.). W 1857 r. powstają Czarne kwiaty i Białe kwiaty, tworzące według specjalistów nowy rodzaj „eseju polskiego"3. Nowa poetyka unikająca wszelkich efektów, „biała”, ma według niego stworzyć polską szkołę literatury. Jej temat to „patos codzienności”.

W 1860 r. przedstawia konferencję o poezji Juliusza Słowackiego - ważny etap jego filozofii kultury. Można uznać, że tu zaczyna się trzeci okres jego dzieła, poświęcony poezji i teatrowi. W 1862 r. publikuje pierwszy zbiór poezji, dzięki któremu zostanie „odkryty” na początku XX w. W 1865-1866 r. pracuje nad drugim zbiorem, który ukaże się dopiero prawie sto lat później, a dzisiaj jest uważany za arcydzieło poetyckie: Vade-mecum - w poetyce nowatorskiej na epokę. Stanie się odwołaniem dla poezji XX-wiecznej.

W trzecim okresie twórczości, powstają też sztuki Norwida w trzech różnych rodzajach: „misteria” (Wanda i Krakus), a po doświadczeniu amerykańskim ,tragedia biała" (Pierścień Wielkiej Damy, Aktor i Za Kulisami), oraz dramat historyczny (Kleopatra i Cezar). Nigdy nie zostaną zrealizowane za życia autora, ale ten teatr poetycki będzie miał później ważny wpływ na teatr polski, i zapowiada pod pewnymi względami styl groteski polskiego teatru absurdu (Gombrowicz, Różewicz...).

W okresie tym powstaje również nowy poemat filozoficzny Rzecz o wolności słowa z 1869 r. Podejście antropologiczne Norwida wkracza tu w nowy wymiar, częściowo kontrowersyjny (jak negacja prac Darwina), ale bogaty w symbole jak opozycja metafory wulkanu, zachwycającej romantyków - i pracy powolnej, cichej, która wytworzyła języki i kultury. Mesjanizmowi rewolucyjnemu romantyków z hasłem Polska - Chrystusem narodów przeciwstawia własną drogę przekształcenia etycznego człowieka przez pracę i sztukę. Przez kulturę. Problematyka

${ }^{3}$ Por. Polski esej literacki. Antologia, wstęp i oprac. J. Tomkowski, Wrocław 2017. 
praxis zajmowała Norwida podobnie jak Marksa i Proudhona, ale nigdy nie zaakceptował walki rewolucyjnej jako drogi wyzwalania ludzi - stawiając na pracę, dojrzewanie i przekształcenie etyczne poprzez rozwój człowieczeństwa człowieka. Kojarzy się go dzisiaj z humanizmem chrześcijańskim i z personalizmem avant la lettre.

Trudno jest ująć w paru punktach bogactwo problematyki socjologicznej i politycznej, literackiej i religijnej, podkładu filozofii i mądrości oraz dialektyki cywilizacji - związanych z naszym tematem. Będzie można je tylko naszkicować.

Jego poetyka uprzywilewuje parabolę, odwołuje się do paradoksów, do ironii, do neologizmów, do archaizmów, tworząc model wiersza białego bliskiego prozy poetyckiej, co pozwala mu na grę na rozmaitych poziomach znaczeń. Zapowiada poezję lingwistyczą, obnażającą rutynę cliché, wyrażeń stereotypowych, polisemię i zbliżanie wyrazów pozornie oddalonych od siebie (jak w wierszu Rozebrana). Pracuje nad wyglądem graficznym słów, podkreśla wyrażenia, intonacje. Tłumaczy to teorię „oralności wtórnej”, pracy nad „partyturami graficznymi”. Nie wspominając o jego teorii milczenia i podtekstów. Porównuje się go dzisiaj do Baudelaire'a i Mallarmégo, do Hopkinsa i do Whitmana, zostanie uznany za jednego z największych poetów swej epoki przez Gide'a, i Bergsona, Miłosza i Różewicza, Jana-Pawła II i Brodsky’ego, przez Holana...

W centrum jego uwagi znajduje się człowiek w perspektywie dualistycznej, zmuszającej do poszukiwania syntezy materii z duchem, w perspektywie uniwersalizmu etycznego przezwyciężającego rozdział pomiędzy kulturą a wyznaniem, wokół symbolu centralnego krzyża, jednocześnie drogi i środka, symbolu nie tyle martyrologii co wysiłku twórczego umożliwiającego odzyskanie człowieczości stworzenia. Mówi się w studiach o nim o dialektyce kwiatu i kamienia: kwiat sam - forma - nie doleci do celu, kamień nadaje mu kierunek - sens. Kamień umożliwia konstrukcję nowego gmachu kultury, drogę prowadzącą do zmartwychwstania - historycznego i eschatologicznego, ukoronowanego kopuła duchów kultur i cywilizacji. Kopuła jest obrazem ,monologu-nieustannie-się-parabolizującego" (Milczenie, PWsz VI, 236). Kultury jako paraboli świata.

\section{„ŁAGODNE OKO BŁĘKITU”}

Norwid fascynuje kontrastami. Z pozoru jest łagodny, jak „oko błękitu” ze słynnego wiersza $W$ Weronie (PWsz II, 22), gdzie jednak obok łez spłukujących „gruzy nieprzyjaznych grodów” pojawiają się spadające z nieba „kamienie” - kosmiczne meteoryty. Kosmos jest u niego obrazem przedwiecznego ładu, ale i katastrof. Jedynie „łagodne oko błękitu” może „planetę zwaśnioną / Zeswoić z Tęczą 
Twórcy rozjaśnioną, [...] / Niż serca ludzi - wpierw nim ludzie zamrą?!" (Tęcza, PWsz I, 311). Pozostaje spojrzenie w niebo i ład kosmosu:

[...] nie ma bynajmniej sieroctwa!

Ja zaś jakoś niechcący ku niebu spojrzałem,

A niebo było gwiaździste;

W gwiazdach więc tajemnicę tych słów wyczytałem,

Bo one tam wyraźne były, oczywiste;

Potem, gdy dusza swego skosztowała chleba,

Nie mogłem się już więcej oderwać od nieba,

Które mnie wciąż ciągnęło silnym, wonnym tchnieniem.

I wtedy to ja, wziąwszy mój łzawy różaniec,

Zmówiłem na nim pacierz - potężnym milczeniem.

(Sieroty, PWsz I, 7-8)

W jednym z pierwszych wierszy już pojawiają się więc motywy katastrofy, gestu spojrzenia w niebo, milczenia i metafizycznego zaufania oraz „wonnego tchnienia".

Ten ostatni motyw tłumaczy „białą” estetykę wierszy Norwida, w nawiązaniu do przejścia Pana z I Księgi Królewskiej:

„Wyjdź, aby stanąć na górze wobec Pana” - rzekł do Eliasza. „A oto Pan przechodził. Gwałtowna wichura rozwalająca góry i druzgocąca skały [szła] przed Panem; ale Pan nie był w wichurze. A po wichurze - trzęsienie ziemi: Pan nie był w trzęsieniu ziemi. Po trzęsieniu ziemi powstał ogień: Pan nie był w ogniu. A po tym ogniu - szmer łagodnego powiewu. Kiedy zaś Eliasz go usłyszał, zasłoniwszy twarz płaszczem, wyszedł i stanął przy wejściu do groty. A wtedy rozległ się głos mówiący do niego ${ }^{4}$.

Głosem Pana jest „łagodny powiew”, pomimo wszystkich katastrof. Norwid starał się iść tym tropem. Chociażby w poemacie Rzecz o wolności słowa, gdzie następuje ekstrapolacja jego polemiki z romantyzmem polskim i naczelną metaforą wulkanu, gdyż Mickiewicz głosił w Dziadach:

[...] Nasz naród jak lawa,

Z wierzchu zimna i twarda, sucha i plugawa,

Lecz wewnętrznego ognia sto lat nie wyziębi;

Plwajmy na tę skorupę i zstąpmy do głębi.

${ }^{4} 1 \mathrm{Krl}$ 19, 11-12, Biblia Tysiąclecia.

${ }^{5}$ A. Mickiewicz, Dziady, cz. III, sc. VII, w: tegoż, Dzieła, III, Wyd. Rocznicowe, Warszawa 
W Rzeczy o wolności słowa Norwid przeciwstawia sile wulkanu - pracę pokoleń:

\author{
Wszelako - acz jest piękne wulkanu natchnienie [...] \\ Myślę... że i ten cichy co rok widok łanu \\ Majestatycznym bywa nie mniej od wulkanu! [...] \\ Ciemnota - która mimo niezgrabne praktyki, \\ Stworzyła Arcydzieła - stworzyła Języki! \\ Tych się nie tworzy sennym natchnienia polotem, \\ Zboże po burzy wstawa, lecz nie siane grzmotem, \\ I raczej praca długa a wierna literze \\ Całokształty takowe urabia i strzeże.
}

(Rzecz o wolności słowa, DW IV, 262-263)

Z wersów tych wyrosła filozofia pracy rozwijana przez Brzozowskiego, Tischnera i Jana Pawła II, oraz ruch „Solidarności”, który wstrząsnął geopolitycznie światem jak tornado. Wtedy to „łagodne oko błękitu” okazało się „okiem cyklonu" o światowych konsekwencjach: samoograniczające się rewolucje 1989 r. w Europie Środkowo-Wschodniej z konsekwencjami obejmującymi świat: upadek ZSRR, koniec świata bipolarnego.... Nastąpiła przemiana paradygmatu kultury, choć jej konsekwencje są obecnie rozmieniane w Polsce na wewnętrzne rozgrywki polityczne.

Istnieje jakaś prawidłowość cyklów dwustuletnich w historii. Po rewolucji francuskiej z 1789 r. przez dwieście lat panował na świecie paradygmat rewolucji jako formy koniecznej dla zmiany ustroju i cyklu dziejowego. Odwoływała się do tego niego rewolucja październikowa i różne następne jak chińska czy kubańska, stanowił model przewrotu, zawsze krwawego. „Solidarność” polska doprowadziła do bezkrwawej, ,samoograniczającej się” rewolucji i z czasem do upadku komunizmu: dwieście lat po rewolucji francuskiej, w 1989 r. Stanowiła przez jakiś czas nowy wzorzec przemian ustrojowych poprzez układy, kompromis i nadrzędny ideał praw człowieka. Nowy paradygmat rewolucji bezkrwawej. Nie wiadomo, ile czasu przetrwa i na ile będzie płodny, ale upadanie dyktatur i ustrojów totalitarnych za czasów Jana Pawła II, oraz wydarzenia ostatniego roku na Białorusi wskazują, iż wzorzec jest stale aktywny. W jakimś stopniu jego duchowym ojcem jest Cyprian Norwid, którego dwusetlecie urodzin obchodzimy.

1995, s. 209. Następnie cytaty z Mickiewicza według tego samego wydania (jako WR): cyfra rzymska oznacza tom, arabska - stronę. 
Słusznie stwierdza Paweł Rojek w książce o polskim mesjanizmie Jana Pawła II:

Wygląda więc na to, że tak jak Polska insurekcyjna była krajem Mickiewicza, Polska międzywojenna - Słowackiego, tak Polska Solidarności miała stać się krajem Norwida. W tej perspektywie pontyfikat Jana Pawła II, twórczość filozoficzna Tischnera oraz wielki ruch Solidarności można uznać za wielki pośmiertny tryumf zmarłego w zapomnieniu poety ${ }^{6}$.

Jego poezja i myśl pod wieloma względami wydają się stale żywe.

Z rzeczy świata tego zostaną tylko dwie,

Dwie tylko: poezja i dobroć... i więcej nic...

(Do Bronisława Z., PWsz II, 238)

Świat obecny wydaje się sterowany nauką, techniką i ekonomią, co zapowiadał już Norwid mówiąc o wieku, ,przemysłowym, handlowym” (Aktor [II], DW $\mathrm{V}, 368)^{7}$. Niemniej spojrzenie antropologów i filozofów jest bardziej zniuansowane. Wielkie metafory tworzą całe cywilizacje (Wheelwright ${ }^{8}$ ): czyż można sobie wyobrazić cywilizację zachodnią bez biblijnej metafory Boga-Ojca, dzięki której ludzie są braćmi (mimo bratobójstwa), ziemia jest wspólnym domem albo świątynią z dwoma lampionami słońcem i księżycem i dywanem trawy?... W innych religiach bóg jest czasem stwórcą ale i tyranem, nie Ojcem. Prace Paula Ricœura o metaforze ukazują, że odniesieniem metafory jest sposób życia-w-świecie, a więc działanie ${ }^{9}$. Spojrzenie poety tworzy świat ludzki i wskazuje jak w nim żyć. Poezja uczy ,życia dobrego", a język religii ma zawsze charakter poetycki ${ }^{10}$. „Łagodne oko błękitu” może się stać w historii „okiem cyklonu” - przemieniać świat na dobre i na złe. Niemniej obecność poezji wprowadza spojrzenie „z góry”, transcendencję, również transcendencję międzyosobową, relacjonalną, poziomą.

W czasie kongresu slawistycznego w Lubljanie ze zdumieniem odkryłem na nowo skonstruowanym budynku olbrzymi napis po angielsku: ,Gagarin said: the sky is dark, the earth is blue". Niebo jest pomiędzy ludźmi, jak w obecnych tłu-

${ }^{6}$ P. RoJek, Liturgia dziejów. Jan Pawet II i polski mesjanizm, Kraków, 2016, s. 220.

${ }^{7}$ Podobnie zatytułowała swój szkic o Norwidzie Zofia STEFAnOwSKa: Pisarz wieku kupieckiego i przemystowego (w: Strona romantyków. Studia o Norwidzie, Lublin 1993, s. 5-54).

${ }^{8} \mathrm{Ph}$. Wheelwright, Metaphore and Reality, Indiana 1962, 1968.

9 P. Ricceur, La métaphore vive, Paris 1975.

${ }^{10}$ Idem, Du texte à l'action, Essais d'herméneutique II, Paris 1986. 
maczeniach Ewangelii, które nie przekładają już, iż „Królestwo Boże jest w was”, ale „,królestwo Boże pośród was jest” (Łk 17, 21, BT) ${ }^{11}$.

\section{ROMANTYZM EPOKI PRZEMYSŁOWEJ}

Pomijając te rozważania egzegetyczne przypomnijmy spór o charakter romantyczny, czy też postromantyczny pisarstwa Norwida. Tematyka jego pism, zwłaszcza po powrocie z Ameryki, dotyczyła cywilizacji „kupieckiej i przemysłowej”, czyli postromantycznej czy wręcz pozytywistycznej, bliskiej Biedermeieru (J. Maciejewski $^{12}$ ), ale rozważania Zofii Stefanowskiej słusznie wydobywają pytania, które swej epoce stawiał:

Przedmiotem krytyki Norwida jest taki romantyzm, na który składa się mesjanizm i postulat martyrologii (gwałt na Opatrzności), wyłączność narodowa i pomijanie problemów ogólnoludzkich, lekceważenie jednostki i negowanie ciągłości bytu narodu niewolnego, oderwanie od rzeczywistości i czasu teraźniejszego, jednostronny spirytualizm i pogarda dla ciała, dla kształtu, dla materii. [...]. Związanie twórczości artystycznej z pracą i zarazem przywrócenie pracy charakteru twórczego przezwyciężyć ma romantyczną opozycję między twórcą i odbiorcą [...]. Sztuka ma pełnić wielorakie funkcje mediacyjne: między ziemską egzystencją a Boskim powołaniem człowieka [...]. Postulowana w Promethidionie działalność praktyczna ma sens $\mathrm{w}$ ramach eschatologicznie rozumianej historii i jest w istocie programem przywrócenia pracy jej funkcji ekspiacyjnych. Tak więc antyromantyczny w intencji postulat zwrotu do rzeczywistości włączony jest w typowo romantyczną koncepcję finalnych celów człowieka ${ }^{13}$.

Stawiał Norwid przed sobą romantyczne pytania i poszukiwał na nie nowych, lepszych odpowiedzi. Odpowiedzi te nie mogły być jednak całkiem nowe, bo kierunek poszukiwań wytyczony był przez romantyczny zespół pytań ${ }^{14}$ :

U Norwida w sposób bardzo interesujący konkurują ze sobą romantyczna koncepcja wieszcza i przywódcy z nowoczesnym rozumieniem zwodu pisarza zarabiającego piórem [...] [ale literatura jest dla niego aktem] ,rozgrywającym się między twórcą i odbiorcą ${ }^{15}$.

${ }^{11}$ Greckie entoshumôn, łac. Wulgata intra vos, ale współczesne wersje (obecne już od XVII w.) pragną ukazać Królestwo nie jako wyłącznie wewnętrzne, a przeżywane we wspólnocie. Niemniej Biblia Gdańska z której Norwid często korzystał thumaczy: „Królestwo Boże bowiem jest wewnątrz was".

12 J. MaCiEJEwski, Cyprian Norwid, Warszawa 1992.

${ }_{13}$ Z. STEFAnOwsKa, „Norwidowski romantyzm”, w: taż, Strona romantyków, s. 64-65, 67-68.

14 Tamże, s. 70.

15 Tamże, s. 81-82. 
Spór o mesjanizm romantyczny zyskał u niego charakter kosmiczny. Norwid przeciwstawiał ład gwiazd - bezużytecznej martyrologii. Najpierw wydobywał romantyczną opozycję nocy i dnia, urojeniom snów - pracy, która jednak zacieśnia rzeczywistość (Wieczór w pustkach, PWsz I, 33). A wszak Homer „cię uczył śpiewać z gwiazdami do chóru?" (Marmur-biały, PWsz I, 100). Najważniejszy jednak wydaje się fragment litanii Do Najświętszej Panny Marii, gdzie kupola gwiazd zapewnia światu stałość opieki Ducha:

Duch każdy w Twoje prorokował łono, Niby że chórem, co przez wieki płynie W gwiazdami litą kupolę przestroną, Rozścielającą się nad wszech-ludami O! Nabożeństwa Dziwnego Naczynie, Módl się za nami...

(PWsz I, 196)

Kupola gwiazd zapewnia spokój, ale nie uchyla perspektywy śmierci:

Patrzyłem w zawrót gwiazd, w wieczne spokoje,

Gdzie do harmonii już Pewność i Trwoga

Dobiegły jako bliźniąt dziwnych dwoje...

[...]

Jak nieszczęśliwych-łza w obliczu Boga...

[...]

Bo i ja jestem śmiertelny - tak mniemam...

([Do Marii Trębickiej], PWsz I, 257-258)

Ostatecznie więc spokój i harmonia gwiazd wcale nie jest spokojna:

Jak się nie nudzić? Gdy oto nad globem Milion gwiazd cichych się świeci, A każda innym jaśnieje sposobem, A wszystko stoi i leci...

(Marionetki, PWsz I, 345)

Harmonia gwiazd nie osłabia tragedii uczuć w świecie ludzi:

W gwiazd harmonię poglądać weseléj

Przez wiele lat samotnych, 
Niż w źrenicach błyskotnych

Wyczytać raz - co? serca rozdzieli!...

(Harmonia, PWsz II, 21)

Bo:

Jak gwiazdy nie tam są gdzie świécą!

(Kolebka-pieśni, PWsz II, 114)

Gwiazdy są jednak pierwowzorem alfabetu z którego powstało słowo:

[...] pierwszym dla ludzi alfabetem był firmament, gwiazdy, konstelacje: tam się wzroki jednały wszystkich wzrok nad ziemię podnoszących, i stamtąd też spadły im pojęcia: pór roku - równań - znaczeń - liter...

(Stowo i litera, PWsz VI, 323)

Ład kosmosu był więc matrycą słowa, ładu ludzkiego, który dopiero człowiek tworzył poprzez pracę (Rzecz o wolności słowa). Walka z mesjanizmem Mickiewicza była zarówno walką z kultem ofiarniczym powstań (Zwolon), jak z przebóstwieniem narodu. Wprawdzie:

Naród że cierpi, więc nie jest ideą,

Lecz jest $w$ ciele nie-żywym, organicznym,

Istotą rzeczy. - Czuć ją, poznać chcę ją...

(Niewola III, DW IV, 59)

Ale nie wolno go absolutyzować. Norwid ironizował:

Oni kochają Polskę jak Pana Boga i dlatego zbawić jej nie mogą, bo cóż ty Panu Bogu pomożesz?

(List do T. Lenartowicza, DW XI, 42)

Decydujące starcie Norwida z Mickiewiczem miało miejsce w Rzymie w 1848 r., kiedy Norwid wypisał się z Legionu włoskiego. A literacko odciął się zdecydowanie od mesjanizmu w Promethidionie (1851), w Bogumile, gdzie przeciwstawił pracę, ,najwyższe z rzemiost apostoła” i „najniższa modlitwę anioła” - ,tatarskiemu czynowi” podbojów budujących bezpłodne cesarstwa. Jedynie twórcza jest:

[...] praca coraz miłością ulizona, Aż się i trudów trud wreszcie wykona.

(DW IV, 117) 
„Trudów trud” nawiązywał oczywiście do żywota Męża czterdzieści-i-cztery z Widzenia księdza Piotra z Dziadów. Emblemat pracy wspólnotowej ludzi miał zająć miejsce mesjanizmu narodowego, dlatego też używamy sformułowania „mesjanizm pracy”. Ma on spełniać funkcję ekspiacyjną i zbawczą. Myśl ta zostanie rozwinięta przez Józefa Tischnera w Etyce Solidarności i stanie u podstaw $10 \mathrm{mi}-$ lionowego ruchu, który przemienił krajobraz geopolityczny Europy Środkowej i Wschodniej, bipolarnego świata, który po 1989 r. rozpadnie się na „cywiliza-

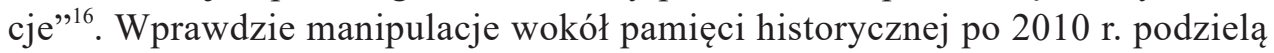
Polskę, emblematyczne słowo „solidarności” zachowa swoją moc i jest stale aktywne na całym świecie i w rozmaitych reżimach.

\section{KOŚCIÓŁ CZŁOWIEKA}

Niezwykle ważne wydają się rozwinięcia teologiczne, inspirowane przez Norwida: Chodzi o encykliki Jana Pawła II Redemptor hominis (1979), Laborem exercens (1981) jak i Centessimus Annus (1991), nie mówiąc o Liście do artystów (1999), cytującym wprost Mickiewicza i Norwida.

Podstawowym odniesieniem mesjanizmu pracy jest słynna metafora o konieczności przemiany świata $\mathrm{w}$ duchu (bo „Ze zbudowania $w$ duchu się buduje" (Promethidion, DW IV, 117), do czego wzywał już Mickiewicz w Odzie do młodości: ,wyjdzie z zamętu świat ducha”(WR I, 44), cytowany przez papieża w Liście do artystów. Norwid doprecyzuje obraz:

- O! nie skończona jeszcze Dziejów praca,

Nie-prze-palony jeszcze glob, Sumieniem!

(Socjalizm, PWsz II, 19)

Pojęcie sumienia zawiera zarówno dążenie do prawdy, do świadomości, jak i do uniwersalizmu etycznego (tłumaczeniem na francuski byłaby „conscience morale", świadomość moralna).

Myśl ta znajduje się w centrum encykliki Jana Pawła II Laborem exercens, gdzie człowiek przez pracę nie tylko wytwarza przedmioty, ale i konstruuje własną osobowość. Chodzi więc o proces hominizacji w wymiarze etycznym. Bezkrwawą rewolucję „Solidarności” wygrano przez sumienie, mobilizację sumień klasy robotniczej która miała legitymizować totalitarny komunizm.

${ }^{16}$ Jak w znanej książce S. P. Huntingtona, Zderzenie cywilizacji i nowy ksztalt ładu światowego, przeł. H. Jankowska, Warszawa 2005. 
Oczywiście warunki polityczne sprzyjały dezawuacji dyktatury proletariatu, czyli partii, ale istotnie metafora Norwidowska zadziałała jak oko cyklonu dziejowego. A ze względu na samoograniczanie, uniknięcie rozlewu krwi - na kopule świata ukazało się również „łagodne oko błękitu”. Owoc pracy sumień, przepalających glob. Oksymoron poetycki połączył cyklon dziejowy ze spojrzeniem Nieba.

O przemianie wyobrażeń transcendencji świadczą metafory związane z „Kościołem” i sakramentami. Kościół w wierszu z 1851 r. - roku wydania Promethidiona - zawiera sformułowania uniwersalistyczne i w jakiś sposób anty-instytucjonalne:

Gdybyście wiarę mieli, to już dawno

Widzielibyście, że glob jest Kościołem,

Który ma oną bazylikę sławną

Piotrową - niby ołtarzem i stołem...

Ale wam trzeba Kościół $w$ oltarz wcisnąć

I zamknąć - i straż postawić przy grobie,

Żeby za prędko nie mógł Bóg wybłysnąć...

- Czekajcież... wstanie On - w cało-osobie.

(Fraszka (!)[III](Petersbursko-Wiedeńskim Papistom przypisana); PWsz I, 170)

Kościół może bowiem zamienić się w miejsce spotkań - w salonik:

...Nim znów ucieknę, nic nie mając zgoła,

W podartym płaszczu, o porze zawiei,

Od zmienionego w salonik kościoła,

Od zamienionej w karczmę epopei [...].

([Nim znów ucieknę, nic nie mając zgoła], PWsz I, 265)

A wszak chrzest jest „Sakramentem Kościoła” (Człowiek, PWsz I, 270). Sam człowiek jest sakramentem:

Nogi ci włosem obetrze - kto? - strumień!

Kto ci obetrze pot z bladego czoła?

Jeśli nie Prawda, Weronika sumień,

Stojąca z chustą swą w progach kościoła?! -

Sakrament, poznasz, że jest jeden stały -

I samą wzgardą pogardzisz na świecie,

Piękny jak świeżo narodzone dziecię,

Ten sam, co dawniej, niby Mojżesz mały,

Nilowej lilii trzymający kwiecie.

(Człowiek, PWsz I, 274) 
Kościół znacznie przekracza rozmiary materialne świątyni. To „glob” cały, ale i wspólnota kultury:

Nie znałeś skąd jest sztandar zasiany piosenką,

Ni kościół skąd duchowy powstaje narodu!

(Echa. Fantazja, PWsz III, 541)

Kościół jest pojęciem transcendentnym:

nad Historią Kościół jest,

pod Historią plemiona, czyli rasy,

a narody tylko są w Historii

(Odpowiedź krytykom „Listów o emigracji”, PWsz VII, 36)

Liczy się człowiek, a nie instytucja, jak w słynnej Fraszce (!) [II]:

Dewocja krzyczy: „Michelet wychodzi z Kościoła!”

Prawda; Dewocja tylko tego nie postrzegła,

Że za kościołem człowiek o ratunek woła,

Że kona - że ażeby krew go nie ubiegła,

To ornat drze cię w pasy i związuje rany.

A faryzeusz mimo idzie zadumany...

(PWsz I, 168)

Takiej dewocji odpowiada „Kościół Tryumfu wysoki” (Cnót-oblicze, PWsz II, 72).

Przeciwstawiony jej jest Zgon Poezji - „w przestronnym milczenia kościele” Na zgon Poezji. (Elegia); PWsz II, 201). Milczeniu, jak wiadomo Norwid poświęcił ważny esej. Wieńczy ten szereg metafor pojęcie „Prawdy wiecznego Kościoła” (Quidam, IX, DW III, 158).

Odpowiednikiem jej jest Msza-Dziejów (PWsz II, 214), czy „Msza-wieczna” (PWsz IX, 60), czy też Msza stworzenia zapowiadającej słowami Ozeasza II, 18 - ,przymierze”: „ze zwierzem polnym i ptastwem powietrznym, i z płazem ziemskim, a łuk i miecz, i wojnę wygładzę z ziemie i dam im spać bezpiecznie" (Ostatnia z bajek, DW VII, 248).

Warto jeszcze podkreślić zdumiewające przeciwstawienie przez Norwida Sakramentu i dobra: „Owo - nie już o Ludzkość, o ten Sakrament, ten akt w wieczności, ten sentyment, ale o rzeczywiste idzie dobro" (Odpowiedź krytykom..., 
PWsz VII, 33). Nie chodzi o „,zbawienie Ludzkości przez naród” (tamże; co jest aluzją krytyczną do mesjanizmu Mickiewicza), ale o powolne, progresywne przebóstwianie świata:

[...] pomiędzy wiecznym a czasowym - jest jakoby pomiędzy dwoma stycznie ku piersiom Przedwiecznego zmierzającymi promieniami, i to, co czasowe, coraz więcej ku wiecznemu schylone, coraz więcej wiecznym zachwycone, aż przez coraz z-bożniejsze czasów sfery do Zbożnego czasu się włonimy [...] o czym pieśń nad kołyską narodu tego brzmi wyraźnie: ,ziści nam - spuści nam - Twego Syna Chrzciciela Z-bożny czas" (PWsz VII, 33).

Wszystkie te metafory kościoła, sakramentu i pracy człowieka zbiegają się w cytacie eseju $Z$ pamiętnika z roku (w którym wyszedł Promethidion), będącym sprawozdaniem z wystawy artystycznej w Paryżu w 1851 r., gdzie Norwid stwierdza: „Sztuka jest kościołem pracy.” (PWsz VI, 375), co zapowiada już Fortepian Szopena z 1865 r., gdzie sublimacja pracy zyskuje wymiar Eucharystyczny (por. mój szkic „Parabole Eucharystyczne Norwida”).

Hominizacja poprzez pracę prowadzi bowiem do rośnięcia człowieka w duchu, a zbiorowa praca zyskuje wymiar transcendencji poziomej, interpersonalnej. Spojrzenie ukazujące, że ,glob jest kościołem” stwarza podstawy uniwersalności etycznej i zapowiada metaforę „Kościoła ludzkości” u Gombrowicza i u Miłosza. Prześmiewczy charakter stwierdzenia Gombrowicza (teza Łukasza Tischnera ${ }^{17}$ ) nie odbiera serio rozważaniom Miłosza ${ }^{18}$. W każdym razie Norwid był pierwszy na tej drodze, dzięki docenieniu pośrednictwa pracy.

Zwykło się podkreślać teistyczny charakter jego wiary, na co można znaleźć wiele cytatów z jego pism. Ale perspektywa antropocentryczna również wydawała mu się bliska a człowiek, osoba wcielająca wartości chrześcijańskie na wzór Chrystusa na krzyżu, był istotą mechanizmu „przepalania globu sumieniem”. Symbolika krzyża miała dla niego wyjątkową wartość emblematyczną, ale, jak podkreślał, krzyż to połączenie wymiaru pionowego z poziomym. Tak też określał istotę powstania sztuki chrześcijańskiej w Epilogu Promethidiona:

Chrystianizm - przez przecięcie linii ziemskiej horyzontalnej i linii nadziemskiej prostopadtej - z nieba padtej, czyli przez znalezienie środka +, to jest przez tajemnicę krzyża (środek po polsku znaczy zarazem sposób) (Epilog, DW IV, 133).

17 Ł. Tischner, Gombrowicza milczenie o Bogu, Kraków 2013.

${ }^{18}$ Każdy występuje jako zależny od „,przestrzeni międzyludzkiej”, czy też, jak to nazywa Gombrowicz, od „międzyludzkiego kościoła”; ludzie już wiedzą, że swoimi gestami, spojrzeniami, słowami, zawsze ,zarażają się wzajemnie. Obrzęd konstruuje przestrzeń sakralną. (Cz. Mııosz, Widzenia nad Zatoka San Francisco, Paryż 1988, s. 169). Por. tegoż, Ziemia Ulro, Paryż 1980, s. 41. 
Czyli środek, centrum i sposób wyznacza istotę życia, tożsamości i celu: to droga krzyża. Droga wcielenia i zmartwychwstawania przez wysiłek, przez od-poczynanie spraw niedopełnionych - przez siebie, przez przodków, przez kulturę. Norwid nie używa słowa „kultura”, ale raczej w tym znaczeniu „sztuka narodowa” (Sawicki), „duch narodowy”, czy ,zmartwychwstanie narodu” (w przeciwieństwie do jego „znicestwienia”). I tu pojawia się problem teologiczny stale aktualny, a mianowicie zmartwychwstania indywidualnego czy wspólnotowego ${ }^{19}$. „Od-poczynać” (,począć na nowo, począć w drugiej potędze” Promethidion, Bogumit, DW IV, 115, przypis $^{20}$ ) bowiem można i należy indywidualnie (Bliscy), ale i zbiorowo. A jeśli kultura, czy duch narodu rozpadnie się na indywidualistyczne jednostki - odnaleźć jedność można tylko poprzez odwołanie do wartości wyższej:

[...] każdy duch, nie szukając siebie, ale celu swego, to jest Duchów-Ducha, uzmartwychwstawia się w ono drugie powietrze, w światłość prawdy... ([Zmartwychwstanie historyczne], PWsz VI, 611)

Duchem-narodu [dzisiaj powiedzielibyśmy „kulturą”] jest moralna-całość narodu” (PWsz VI, 613). [...] Naród [...] musi z ducha na nowo się odrodzić, musi zmartwychwstania pracę wszcząć. Żadna bowiem moralna-catość bez Ducha Świętego nie istnieje" (tamże).

Oto dlatego, że śmierć narodu jest z zaparcia się ducha, czyli całości-moralnej-narodu, więc na pojedynczości, na osobne całości rozsypuje się całość narodowa, i tyle jest ducha ile duchów, tyle Osoby narodu [=kultury] ile osobistości narodowych, tyle historii narodu, ile biografii i martyrologii narodowej [...]. Oto dlatego, że tylko przez całość wyższą od tej, której się zaparło, powrócić w prawdzie można do niej - to jest przez Ludzkość do Ojczyzny. (PWsz VI, 614-615)

\section{Stąd wynika, iż:}

Znicestwić żadnego narodu nikt nie podoła bez współdziałania obywateli tegoż narodu, i to nie bez współdziałania przypadkowego, częściowego, nominalnego, ale bez współdziałania starannego. ([Znicestwienie narodu] z 1871 r., PWsz VII, 85).

\section{A ponieważ żaden naród nie żyje sam:}

[...] narody europejskie wyżej niż które inne posiąść powinny całe osobistości własne, albowiem osobistość na samotność wydalona nie jest jeszcze pełną, i dopiero przez obcowanie z osobistościami innymi wydojrzewa na właściwą istotność. Tak dalece, że jeżeli powiedziało się, iż naród składa się nie tylko z tego co wyróżnia go od innych, lecz i z tego co do z in-

19 Por. B. WoŁoszyn, Norwid ocala. Heroizm, śmierć i zmartwychwstanie w twórczości postromantyka, Kraków, Collombinum, 2008. Por. też Benedykt XVI, encyklika Spe salvi, 2007.

${ }^{20}$ Por. też Bliscy, PWsz II, 76: „w swój wtóry wnikłszy od-początek”. 
nymi łaczy ${ }^{21}$, to powiedziało się zarazem, iż ta połączalności siła nie jest żadnym ustępstwem, a tym mniej uszczerbkiem, ale owszem przymiotem zupełności charakteru i własnością dodatnią ([Znicestwienie narodu], PWsz VII, 86).

(Jakże to aktualne w sytuacji obecnej „wojny kulturowej” w Polsce).

Kluczem do pojęć i języka Norwida stała się, jak niezwykle słusznie podkreśla Zdzisław Łapiński określona „grupa odniesienia”. Wyrażenie „naród europejski” w liczbie pojedynczej „wymownie podkreśla niesamodzielność poszczególnych krajów naszego kontynentu”, „chrześcijaństwo [zaś jest to] jedyny wówczas sprawdzony społecznie uniwersalizm - w dziedzinie ideologii i instytucji". "O pierwszym Norwidzie wolno nam powiedzieć, że jest to pisarz polskiej inteligencji”. Bowiem „w połowie wieku XIX inteligencja zaczęła zastępować szlachtę jako warstwa kulturotwórcza i jako wyrazicielka świadomości zbiorowej społeczeństwa”22. Ale była nieliczna ${ }^{23}$. „Jeżeli zechcemy obecnie nieco dokładniej określić „grupę odniesienia” Norwida, trzeba będzie stwierdzić, iż nie jest nią aktualnie istniejąca inteligencja, lecz ta, która - jak miał poeta nadzieję powstanie w przyszłości”24. I dalej Łapiński stwierdza: „Nie zastawszy godnego swych czasów języka, którym można by wypowiedzieć nowe treści, postanawia Norwid język ten powołać do życia. Poeta zamierza dokonywać swych poetyckich zabiegów na materiale kształtującego się dopiero wariantu polszczyzny - dostosowanego do potrzeb warstwy inteligenckiej” ${ }^{\prime 25}$. „Norwid [...] musiał dokonać roboty podwójnej. Formułował poetycko ujętą myśl i budował jej dyskursywne zaplecze"26. Inaczej ujmując: tworzył nowy, aktualny język inteligencji i jej problematykę.

Konstruował przez nowy język nową warstwę, która miała stać się kopuła świadomości społecznej. Metafora kopuły pojawiła się już w Promethidionie. Przypomnijmy:

Te zaś dwie całości w dialogu onej myśli ludowej ze społeczna nieustannym przestają [...] Taka to jest architektura onej kupoli niewidzianej, w której siedzi skrzydlaty $d u c h$ narodu i psalmów wstęgi prześpiewuje... (Epilog XIII, DW IV, 137).

\footnotetext{
${ }^{21}$ Por. Promethidion, Epilog XIII.

22 Z. ŁAPIŃSKi, Norwid, Kraków 1971, s. 155, 156,

${ }^{23}$ ŁAPIŃsKI, s. 160 cytuje listy do A. Cieszkowskiego z grudnia 1864; PWsz IX, 150 i do M. Sokołowskiego z 1865 r.

${ }^{24}$ ŁAPIŃSKI, s. 161.

25 Tamże, s. 163.

26 Tamże, s. 165.
} 
Obraz kopuły wznosi się pionowo i rozszerza poziomo, łącząc oba wymiary, jak krzyż, ale i obejmując przestrzeń - tworząc całość zarówno relacjonalną jak transcendentną. Warto przypomnieć, że podobnej metafory użył paręnaście lat później Mickiewicz w wykładach paryskich przy omawianiu Legendy Krasińskiego, gdzie kopuła Bazyliki św. Piotra wali się w proch sypiąc. Ale w komentarzu Mickiewicza hufiec pielgrzymów polskich podtrzymuje kopułę szablami:

Nie oręż ziemski ani oręż jednostek zdoła ją ocalić, ale duchy narodów. Duchy narodów podtrzymają tę kopułę, zagrożoną runięciem. Przebiją w niej otwór dla światła niebieskiego, aby była podobna do owego panteonu, którego jest odtworzeniem, aby się znowu stała bazyliką całego świata, panteonem, pankosmosem, pandemonium, świątynią wszystkich duchów, aby dała nam klucz do wszystkich tradycji i wszystkich filozofii. [...] Wielkie bowiem narody i wielcy ludzie Europy nie przestali pracować dla Kościoła (Literatura stowiańska, WR XI, 44).

Otóż, wracając do Norwida, inteligencja miała się stać zapewne „kupolą” narodu, jego świadomością, sumieniem, zwornikiem. Zarówno wzwyż jak wszerz. Stała się parabolą kultury. Co tłumaczy także przywiązanie Norwida do paraboli jako tropu literackiego, łączącego materialne $\mathrm{z}$ duchowym.

Takim dziełem parabolicznym - kopułą kultury - stał się już Promethidion, który - jak słusznie stwierdza Stefan Sawicki - „stał się przecież ambitnym programem tworzenia narodowej kultury, a nawet więcej: proroczym przesłaniem do narodu, wskazującym mu drogę wyzwolenia zarówno z ułomności własnej tradycji, jak i z zewnętrznej niewoli”27.

By kultura stała się żywa i autentyczna musi się oprzeć o wcielanie prawdy, do której każdy dochodzi samemu, ale i poprzez zbiorowy wysiłek. Kluczem jest neologizm „od-poczynać”, czyli „począć na nowo, począć w drugiej potędze”, jak już była mowa. Odsyła on z kolei do „wcielenia” jako „spajania ducha z materią" ${ }^{2}$. Beata Wołoszyn rozwija emblematyczne znaczenie krzyża: „Kultura chrześcijańska zawiera się w tajemnicy krzyża, ale, co warto podkreślić, krzyż nie jest rozumiany jako znak odkupicielskiej śmierci Chrystusa, ani też jako znak cierpienia, lecz jest symbolem wcielenia na wzór zstępującego na ziemię Boga-Człowieka”. I dalej: „Historia to dzieje wcielenia nie tylko w sensie historiozbawczej pracy niwelującej skutki grzechu pierworodnego, ale także w sensie głęboko chrystologicznym - jako nieustanne dopełnianie wcielenia Chrystusowego"29. A „sumienie to prawda wcielona w duszy poszczególnego człowieka”, ale też „słowo

27 S. SAwicki, Wstęp do C. Norwid, Promethidion, Kraków 1997, s. 32.

28 B. Woloszyn, 'Wcielenie'w trudnym świecie pojęć Norwida, w: Trudny Norwid, red. P. Chlebowski, Lublin 2013, s. 120.

29 Tamże, s. 124-125. 
musi zyskać byt publiczny, musi przekonać ogół by się wcielić”30. „Norwid tak silnie akcentował społeczny wymiar zbawienia, że zbawienie jednostki starał się usytuować w perspektywie zbawienia wspólnotowego, czyli historii zbawienia"31. W Niewoli zanotuje: ,W sobie $i$ w dziejach ja ukrzyżowanym!” (DW IV, 57). Bo „człowiek, realizując siebie, realizuje historię”32.

„Żeby bowiem utożsamić pojęcie sztuki i pracy, a następnie rozszerzyć je znaczeniowo w kierunku współczesnego pojęcia kultury stosuje poeta prostą egzemplifikację różnych typów działalności twórczej człowieka, a następnie amplifikację takich przykładów (Promethidion)" - rozwija tę myśl Wołoszyn ${ }^{33}$.

\section{NARÓD, CESARSTWO, CYWILIZACJA}

Przeciwieństwem narodu ze swoją kulturą jest „cesarstwo” - źródło niewoli. Zniewalające zwłaszcza Europę Środkowo-Wschodnią:

Lecz tobie w Rosji, bracie Słowianinie, Cezarska-formę przynieśli z zachodu I na rodzimej postawiono gminie,

Tak że Cesarstwo mas, nie masz Narodu!

A tobie, Czechu, i bracie Rusinie,

Cezarską formę przynieśli z południa,

Co Czeskich, Ruskich, gdy napotka w gminie,

Bierze - i sobie na Carskich przeludnia -

A ciebie, ciebie, Polsko! - formy trzema

Przykryto, Bogu kłamiąc jako Kain, Iż życia więcej pod formami nie ma-

Że się zapadły i obszary krain --

Ale Bóg spyta - On - co Sam jest celem

I życiem: ,Kto tu pustych form czcicielem?

(Niewola I, DW IV, 50)

\footnotetext{
30 Tamże, s. 128.

31 Tamże, s. 129.

32 Woloszyn, 'Wcielenie', s. 131.

33 Tamże, s. 132.
} 
Otóż zmartwychwstanie polega na przezwyciężeniu formy:

Bo wolność?... jest to celem przetrawienie

Doczesnej formy. Oto wyzwolenie!... (tamże).

Wiem - że i naród formy miewa różne, Jak człowiek szaty świetne i podróżne, Lecz wiem, że formę gdy zdejmiesz z narodu, To jeszcze będzie walczył wieki całe O te, co w życiu ma, formy dostałe A wiem, że cesarz gdy bezdzietnie skona,

Cała historia cesarstwa skończona! Że - i Minister czasem lub wikary Cesarstwo z sobą wywleka na mary...

(Niewola I, DW IV, 51)

Naród ze swą kulturą, czyli tożsamością przeżyje cesarstwa, gdyż jedno jest tylko „Cesarstwo-cesarstw” - Chrystusa, bo „wolność tam jest gdzie Duch Pański czuwa" (Niewola, DW IV, 54).

Stąd słynna metafora z Promethidiona już przywoływana, przeciwstawiająca podbój i pracę:

Nie on tatarski czyn, krwawa drabina

Na rusztowanie czerwone łunami

W cesarstwie tego tu świata Kaina,

Lecz konań wielki psalm z wykonaniami!

Lecz praca coraz miłościa ulżona,

Aż się i trudów trud wreszcie wykona.

(DW IV, 117)

Pojawia się jeszcze u Norwida „Apostolskie cesarstwo” ([O polskiej władzy prawowitej], PWsz VII, 168) jako nawiązanie do „Cesarstwa-cesarstw” chrześcijańskiego.

Wprawdzie bowiem narody zrodziły się z cesarstw, ale kultury nadają im tożsamość i formują sumienie poprzez poszukiwanie prawdy. Problematyka cesarstw-cywilizacji pojawi się jeszcze u Norwida w sensie dialektyki historycznego rozwoju, gdzie z kolei będą sobie przeciwstawiane cywilizacje: egipska spod znaku mumii, i twórcza choć wojownicza - rzymska, czy też Spartańska - „zżeleźniała" oraz ateńska - rodząca humanizm (Kleopatra i Cezar, Tyrtej).

Dialektyka cywilizacji zostanie dobitnie i okrutnie zarysowana w wierszach Pieśn od ziemi naszej, Dookoła ziemi naszej czy Memento, gdzie Polska znajdzie 
się „między Azji tchnieniem a Zachodem” (PWsz I, 386). Należy jednak wyjaśnić termin ,cywilizacji”, jak się ma do „cesarstwa” i „,narodu”. Nie jest to zawsze jasne. Internetowy Stownik języka Cypriana Norwida (pod red. Jadwigi Puzyniny i Tomasza Korpysza) określa „cywilizację” jako „stan, etap rozwoju duchowego i materialnego jakiejś społeczności lub całej ludzkości 'także przen.”'. Pojawiają się więc użycia takie jak „cywilizacja chrześcijańska”, „europejska”, polska”, „chińska” - z odcieniami ironicznym, technicznym bądź filozoficznym jak:

Cywilizacja europejska jest bękarcia... [...] Dlatego że wszystkie inteligencje praktyczne są niechrześcijańskie - a wszystkie chrześcijańskie są niepraktyczne!...

(Za kulisami. Fantazja, DW VI, 88 (stwierdzenie Omegitta w rozmowie z Fiołkami)

Pojawiają się też pojęcia - by tak rzec - archeologiczne:

Cywilizacja składa się z nabytków wiedzy izraelskiej - greckiej-rzymskiej, a łono jej - chrześcijańskie - czy myślisz, że w świadomej siebie rzeczywistości już tryumfalnie rozbłysło?

(Quidam. Przypowieść: Do Z. K. Wyjątek z listu, DW III, 120)

Ważne i interesujące jest zestawienie pojęcia „narodu”, czyli kultury z „,cywilizacją". Bowiem:

słowo narodu widzieliśmy [m. in.] - w cało-stowie-narodu, tj. w STYLu, który jest: 1. pokojem wszech elementów narodowych, 2. pokojem między narodem a cywilizacją, tj. sŁoWEM-EPOKI...

(Stowo i litera, PWsz VI, 320)

Ale „cywilizacja” to także technika - Norwid przywołuje Legendę Krasińskiego:

„Wielki to i posępny okręt, bez płócien i masztów, a wszystkie fale kołami rozbija na pianę - i z pośrodka jego bucha słup dymu, który leci nazad w nieskończoność". (Okręt ten jest to arkan cywilizacji całej, w której żyjemy: wozy i okręty parowe, mechanicznie wiążące i popędzające ludy).

(O Juliuszu Stowackim, PWsz VI, 440)

Ale starcie cywilizacji azjatyckiej z chrześcijańską jest ważniejsze, bo globalne i antropocentryczne - przywołane na przykładzie Króla-Ducha Słowackiego: 
Poeta określa spotkanie z Azji przeprowadzonego „Ja” w Iwanie Groźnym z wszechmocnym cywilizacji chrześcijańskiej „nie-Ja”. [...] [Bowiem] „Co znaczy ten Bóg blady? - oto BógSyn, Bóg-umęczony - Bóg-człowiek w chwili śmierci i zwycięstwa swego na ziemi!

(O Juliuszu Stowackim, PWsz VI, 454)

Swoistym podsumowaniem tych rozważań jest stwierdzenie z listu do Władysława Czartoryskiego:

„...W warunkach Cywilizacji Chrześcijańskiej [...] słowo chrześcijańskie mniej ma osobistości (lubo więcej mocy i twórczego żywiołu) [...]. Słowo w warunkach cywilizacji jest raczej dramatyczne niż osobiste.

(List do Władysława Czartoryskiego z czerwca 1866; PWsz IX, 227)

Wprowadza nas to w dramatyzm dialektyki cywilizacji, czy też ,zderzenia cywilizacji”, by odwołać się do współczesnych teorii. Fernand Braudel, wybitny historyk, współtwórca szkoły Annales i pojęcia „długiego trwania”, jak i w pewnym stopniu „historii mentalności” określa cywilizacje jako przestrzeń ze swoistym klimatem, ukształtowaniem, wegetacją, światem zwierząt i specyficznymi zdobyczami. Przede wszystkim jednak kulturą z pewnymi dominującymi cechami. Granice nigdy nie są ścisłe i nieprzekraczalne. Społeczeństwo nigdy nie jest rozdzielne od cywilizacji. Ważna jest obecność miast. Cywilizacje charakteryzuje zbiorowa mentalność (psychika, oporządzenie intelektualne). Najsilniejszą cechą cywilizacji jest religia, jej przeszłość i teraźniejszość. Wreszcie cywilizacje charakteryzuje ciągłość, mimo kolejnych epok. Przemiany, wydarzenia, bohaterowie zajmują odrębne miejsce w historii cywilizacji. Cywilizacje posiadają również specyficzne struktury, charakteryzujące „długie trwanie”. Zbliżenia lub odrzucanie wzajemne cywilizacji, przeważnie nieświadome, powoduje jednak ich wolne przekształcenia. Zderzenia cywilizacji są przeważnie gwałtowne i tragiczne, ale w długim trwaniu nieskuteczne. Ostatecznie - stwierdza badacz - cywilizacja nie jest ani ekonomią, ani danym społeczeństwem, ale tym co poprzez serię struktur ekonomicznych i społecznych dalej trwa, przemieniając się powolnie i z dużym trudem ${ }^{34}$.

Pojęcie cywilizacji zostało podjęte współcześnie przez Samuela H. Huntingtona w Zderzeniu cywilizacji, opisującym świat po upadku komunizmu i bipolarnego podziału sfer wpływów. Wyróżnia on siedem (lub osiem) cywilizacji, na

${ }^{34}$ F. Braudel, Grammaire des civilisations, Paris 1987, s. 49-83. Por. wyd. pol. Gramatyka cywilizacji, przeł. H. Igalson-Tygielska, Warszawa 2006. 
granicach których obecnie dochodzić będzie do konfliktów ${ }^{35}$, co się w dużej mierze sprawdza, mimo kontrowersji związanych z samą teorią, zapewne zbyt esencjalistyczną.

To odniesienie do współczesnych pojęć, rozdzielających „cesarstwa” od „kultur narodowych” i od chrześcijańskiego „Cesarstwa cesarstw” Norwida pozwala nam podjąć poważnie jego metaforyczne podziały z kilku wymienionych już wierszy, pisanych w okresie powstania styczniowego.

Najostrzejsza jest Pieśń od ziemi naszej, gdzie przeciwstawiony jest z jednej strony Wschód - „mądrość-kłamstwa i ciemnota, / Karności harap lub samotrzask z złota, / Trąd, jad i brud” (PWsz I, 123) - drugiej strony Zachodowi - „kłamstwo-wiedzy i błyskotność, / Formalizm prawdy - wnętrzna bez-istotność, / A pycha pych!” (ibid.). Wymienia jeszcze północ „,- Zachód ze Wschodem w zespoleniu” i południe ,- nadzieja w zwątpieniu”. Niewątpliwie jednak najważniejsze jest przeciwstawienie Zachodu ze Wschodem, czyli Rosją: cywilizacji zachodniej z bizantyńską:

Gdy ducha z mózgu nie wywikłasz tkanin, Wtedy cię czekam - ja głupi Słowianin Zachodzie - ty!...

A tobie Wschodzie, znaczę dzień-widzenia, Gdy już jednego nie będzie sumienia W ogromni twej.

(PWsz I, 124)

Czyli poeta stawia Słowianina w opozycji zarówno do Wschodu jak do Zacho$\mathrm{du}$ - Wschodu zbyt wbitego w ziemię a zarazem spirytualnego, i Zachodu zbyt wpatrzonego w niebo a zarytego w ziemi - jak w wierszu Sen.

W następnym wierszu tego cyklu Dookoła ziemi naszej powraca pojęcie cesarstwa w opozycji do Europy Środkowo-Wschodniej:

I wypełnionym będzie ogrom grzechu

Staro-rzymskiego... Rusie! - Czechu! - Lechu!

(PWsz I, 125)

Następuje potem zapowiedź odrodzenia tych kultur w duchu chrześcijańskim:

35 Jak islamu z Zachodem, czy z Indiami, czy wreszcie ostatnio napięcia z Chinami. Wymienione cywilizacje to zachodnia, bizantyjska (prawosławna), islamska, hinduistyczna, chińska, buddyjska, japońska i latynoamerykańska; afrykańska jest w trakcie rekompozycji. 
I znajdziesz żywot w śmierci, a potęgę

W słabości, w słowie latającym księgę,

W ciemności jasność, a w jasności cienie!

To wiedz - i z plewy szczere czyść nasienie.

(PWsz I, 126)

Ta mocno spleciona tkanina prac przezwyciężająca doświadczenie życia i wysiłku poprzez pracę „plewienia” nasienia - nawiązuje jakoś także do Bogurodzicy.

Przede wszystkim jednak stawia nacisk na procesualny a nie esencjonalistycz$n y$ charakter kultur narodowych - jak i cywilizacji. I mimo jedności organicznej „narodu który cierpi” - otwiera też perspektywę stawania się, zmartwychwstawania, od-poczynania, tak życia indywidualnego co zbiorowego.

\section{GESTUALNA MATERIA WIERSZY}

Należy tu przypomnieć, że materią jego wierszy i metafor poetyckich są przede wszystkim gesty i zachowania - zasadnicza materia kultury. Jest to oczywiste w dramatach Norwida, jak to podkreślała Irena Sławińska, zwłaszcza w znanej książce Sceniczny gest poety ze słynnym szkicem „'Ciąg scenicznych gestów' w teatrze Norwida" ${ }^{36}$, ale i w innych swych książkach o poecie, zwłaszcza w Reżyserskiej ręce Norwida ${ }^{37}$. W tej ostatniej książce zastosowała nawet klucz gestów i zachowań do interpretacji prozy epickiej - nowel. Niemniej również szereg wierszy i poematów zawiera elementy dialogu, mikrodramatu, sytuacji dramatycznej. Gdyż „wszelkie rozmyślanie nie przebiega w samotności, wymaga partnera”, stwierdza Michał Głowiński w słynnym szkicu „Norwidowska druga osoba" ${ }^{38}$. Poeta „od razu przeto czyni odbiorcę też współpartnerem medytacji, a więc - w jakimś sensie - uczestnikiem dramatu” ${ }^{39}$. „Powiedzieć można, że poezja Norwida jest poezją zawsze polifoniczną [w znaczeniu Bachtina], poezją wielu racji i wielu postaw, wchodzących z sobą w różnorakie związki. Poezją dyskusji nieustającej" ${ }^{40}$.

${ }^{36}$ Kraków 1960.
${ }^{37}$ Kraków 1971.
${ }^{38}$ M. GŁowIŃSKI, Intertekstualność, groteska, parabola. Szkice ogólne i interpretacje, Kraków 2000, s. 342.

39 Tamże, s. 345.

40 Tamże, s. 346. 
Stwierdzenia Głowińskiego stały się punktem wyjścia ważnej książki Józefa Ferta Norwid poeta dialog $u^{41}$. Pomijając fakt szeroko znany, że większość sytuacji u Norwida rozgrywa się w salonie, badacz wydobywa sformułowania takie jak „,chór spojrzeń” (s. 27), modlitwę jako rozmowę z Bogiem (s. 84) milczenie (s. 81: „zmówiłem z nim pacierz - potężnym milczeniem”), słuchanie (s. 87), gesty i postawy (s. 85), dialog jako obcowanie (s. 93), wagę „obecności” (s. 114); wreszcie typologię relacji osobowych (s. 147).

Problem dialogiczności Norwida czy dominującego monologu dzieli jednak badaczy. Z jednej strony bowiem Mieczysław Jastrun stwierdza: „Ta poezja prawdy wewnętrznej, poezja [...] 'wiecznego człowieka', musiała monologować [bo] kto mówi rzeczy trudne, czy niemożliwe do wyrażenia pełnym głosem, temu pozostaje monolog, nawet wtedy, gdy podzieli go na głosy"42. Takie ujęcie nie przeczy poszukiwaniu dialogu, ale podporządkowuje je w jakimś stopniu metaforze ,tonu wewnętrznego"43. Podobnie S. Świontek uważa, że w dramatach Norwida występuje nadrzędny głos wewnętrzny poety i spojrzenie scalające Widza i Sprawcy ${ }^{44}$. Stefan Sawicki również stwierdza, że „Norwid nie jest poetą dialogu. 'Ty' czy 'wy' liryczne są mu potrzebne nie tyle po to, aby mieć równorzędnego partnera rozmowy, ile po to, aby kogoś przekonać, komuś się przeciwstawić, aby 'odbić się' od czyjejś postawy, poglądów i sformułować czy zasugerować poprzez tę negatywną sytuację stanowisko własne" ${ }^{\text {"45. }}$

Ale z drugiej strony pragnienie rozmowy, kontaktu z innym jest u Norwida, nawet niezaspokojone - niemal obsesyjne! Staje pytanie: czy ta trudność dialogu i pragnienie spotkania nie wiążą się z postawą monologisty, jako tego, który naucza. Postawy Mistrza - Nauczyciela, odżywającego w spotkaniu z uczniami. Spotkanie jest związane żywym słowem. We wstępie do Rzeczy o wolności słowa Norwid pisał: „Głos żywy ma do siebie, że: nikt nigdy dwa razy nie wypowiedział tychże samych rzeczy tymże samym wydźwiękiem i gestem. Słowo więc raz rzeczone ma niepowrotność swą" (DW IV, 215). Ważnym ideałem Norwida był Sokrates, nauczający słowem i czynem, dający życiem świadectwo prawdzie.

Jest charakterystyczne, że kategoria nauczyciela - Mistrza, odgrywa ważną rolę w filozofii Lévinasa, co może być nam pomocne, by zrozumieć implikacje takiej postawy. Notuje on:

41 Wrocław 1982.

${ }^{42}$ M. JASTRUN, Gwiaździsty diament, Warszawa 1971, s. 63-64.

${ }^{43}$ Tamże, s. 60.

${ }^{44}$ S. ŚwionteK, Norwidowski teatr świata, Łódź 1983, s. 182: „Jest to porządek ustanowiony przez ukrytego Widza tego teatru, ale zarazem jego Sprawcę".

45 S. SAwicki, Wartość - sacrum - Norwid, Lublin 1994, s. 196. 
Idee oświecają mnie dzięki mistrzowi, nauczycielowi, który mi je przedstawia [...]. Mistrz - jednoczenie nauczania z nauczającym - nie jest żadnym faktem. Obecność mistrza, który uczy, pokonuje anarchię faktu ${ }^{46}$.

Bo wciela idee, które głosi, dodałby Norwid. Lévinas pisze dalej: ,relacja z innym człowiekiem, naszym mistrzem, dopiero prawdę umożliwia"47. Co jest w jakimś stopniu analogiczne do słów Norwida z Promethidiona:

\section{[...] Prawdy powietrze}

Póki jest czyste, wszystko się rozwija -

Weselsze kwiaty, liście w sobie letsze, Jaśniejszy lilii dzban, smuklejsza szyja,

Wolniejszy człeka ruch i myśli człeka...

(dialog Wiestaw, DW IV, 127-128)

Norwid jest w pewnym sensie takim Mistrzem i nauczycielem, który wciela Innego, wciela Mądrość - a wciela ją własnym Głosem, a nie tylko pismem. Ciekawym dopełnieniem tej dyskusji jest artykuł Pauliny Abriszewskiej o ,tęsknocie Norwida za oralnością" "48. Niuansuje ona tezę Zofii Mitosek o przede wszystkim piśmiennym charakterze poezji Norwida ${ }^{49}$, podkreślając ambiwalencję poety rozdartego niejako między przywiązaniem do żywego słowa a utrwalającym pamięć pismem (zdecydowanie za to wrogiego w stosunku do „cywilizacji druku").

Otóż „kultura oralna zbudowana jest na relacji mistrz-uczeń. Nauczyciel potwierdza prawdę swoją osobą, pismo zaś redukuje niemalże do zera rolę autorytetu" ${ }^{\prime 50}$. Na to nakłada się przeciwstawianie przez Norwida ,filozofii mądrości (heroicznej) - filozofii wiedzy (systemowej)", reprezentowanych emblematycznie przez Ajschylosa i Arystotelesa ${ }^{51}$. Tradycja Sokratejska uczyła ,„praktykowania prawdy”

46 E. LÉVINAS, Całość i nieskończoność. Esej o zewnętrzności, przeł. M. Kowalska, Warszawa 1998, s. 67.

47 Tamże, s. 70.

48 P. AbrisZewSKa, XIX-wieczna tęsknota za oralnością. Przypadek Norwida, „Studia Norwidiana" 32: 2014, s. 25-40.

49 Z. Mitosek, Przerwana pieśń. O funkcji podkreśleń w poezji Norwida, „Pamiętnik Literacki” 1986, z. 3 .

${ }^{50}$ AbriszewsKa, s. 31.

${ }^{51}$ Tamże, s. 32. Badaczka odwołuje się do prelekcji O Juliuszu Stowackim, i do Platona, a następie do Milczenia (PWsz VI, 247). 
w przeciwieństwie do abstrakcyjności, tautologiczności systemu ${ }^{52}$. Nawet jeśli nie ma prostego powrotu do kultury oralnej, ,drukowane księgi związane są z pozorną, systematyczną wiedzą, prawdziwa mądrość wiąże się z działającym wymiarem wielkich słów, brzmiących w dziejach człowieka" ${ }^{53}$. Według Abriszewskiej, proceder specyficznej grafii Norwida jest raczej swoistą partyturą - ,instrukcją oralnego wykonania" i ,odpowiednikiem gestu autora” ${ }^{\text {". }}$. Takie rozumienie wersyfikacji Norwidowskiej mogłoby zostać wzmocnione cytatem ze szkicu $O$ deklama$c j i$, gdzie Norwid postuluje, iż chodzi o to, ,ażeby słowa pisarza tak wygłosić, jak duch pisarza onego poczynał je..." (O deklamacji, PWsz VI, 483). Stąd się zrodzi Redutowa szkoła deklamacji Osterwy, i potem Teatr Rapsodyczny.

Analogiczną, szeroko rozwiniętą krytykę tezy o Norwidzie jako poecie pisma rozwija też Agnieszka Ziołowicz ${ }^{55}$, odwołując się do terminu Jacka Goody'ego „lektooralności”"56: „pisarz posługuje się żywą mową jako człowiek epoki pisma, druku" ${ }^{\text {57 }}$. Jest to rodzaj nie tyle kompromisu, co próby syntezy wartości obu zjawisk: i pisma, i oralności. Ziołowicz stwierdza: „wykładowca [...] głosząc prawdę, nadaje jej cielesną postać - świadczą o niej jego głos, gesty, zachowania, współtworzące wykład jako quasi-przedstawienie" ${ }^{, 8}$. I dopełnia tę myśl w przypisie cytatem z Noty Norwida (Suplement): „Ton, gest (gesta znaczy przecież historie ludu), apolog mimiką i tonem rzeczony był główną posadą tego periodu języków, czyli spólnego języka” (PWsz VII, 450). Obowiązuje „,zasada tożsamości słowa i życia, słowa i prawdy, słowa i czynu"59. To zasada Mądrości, zarówno głoszonej jak i wcielanej przez Mistrza.

Na pokrewieństwo poezji Norwida z biblijnymi Księgami Mądrości zwracał też uwagę Stefan Sawicki: ,„poezja była dla niego [...] gromadzeniem mądrości, człowieczą księgą żywota"60.

Ton mądrości właśnie nadaje wierszom Vade-mecum charakter przykazań-drogowskazów o których pisała Feliksiak, a obecność w Dedykacji tematu rozmowy „błogiej, poufnej i częstej” jest świadectwem wcielania ideału. W wierszach Poeta

52 Tamże.

53 Tamże, s. 35. Autorka odwołuje się do cytatów z Wielkich słów.

54 Tamże, s. 37, 38.

55 A. ZıoŁowicz, Cypriana Norwida sztuka żywego słowa, „Ruch Literacki” LVIII: 2017, Z. 4, s. 359-376.

56 J. Goody, Mit, rytuat i oralność, przeł. O. Kaczmarek, Warszawa 2012.

57 Ziolowicz, s. 360.

58 Tamże, s. 366.

59 Ziolowicz, s. 365.

${ }^{60}$ SAWICKI, Wartość, s. 207. 
występuje jako Mistrz-nauczyciel, nawet jeśli rozmowa z natury swej jest egalitarna, a kontakt z wierszami jest graficzny (wizualny). Stosunek ucznia i nauczyciela ma bowiem charakter rodzaju odpowiedzialnej miłości, zbliżonej do hebr. chesed, tłumaczonego często jako życzliwośćć ${ }^{\text {. }}$.

Jego wiersze są więc rozmowami, czy przedłużeniem rozmów, listów, wymiany zdań, i mają charakter dialogiczny, jak to wykazywał Józef Fert, ale o specyficznym charakterze dialogu Mistrza-nauczyciela ze słuchaczami (uczniami?). Paradoksalnie poezja Norwida ma zarazem ton monologu, nadający jedność osobową wierszom, ale i dialogu, bo wchodzi w siatkę wymiany i starć opinii międzyludzkiej, kumulując dystans mądrości i otwierając wrota wyboru.

\section{UNIWERSALIZM ETYCZNY}

Myśl Norwida jest antropocentryczna. Świadczy o tym choćby metafora, że „piękno jest formą miłości”, albo „profilem Bożym”. To samo z prawdą, czyli z dobrem Trzy idee platońskie są miejscami obecności Boga w świecie. Czyli Bóg jest wcielony w świecie w sztuce, w dobru i w prawdzie - których człowiek ma poszukiwać i je wcielać. Myśl Norwida o pracy podjął Jan Paweł II w książce Osoba i czyn, ale przede wszystkim w encyklice Laborem exercens, gdzie wskazał, że człowiek przez pracę nie tylko wytwarza produkty, ile przede wszystkim konstruuje siebie, co jest głęboką prawdą antropologiczną zarówno całego procesu hominizacji, jak też indywidualnego przebiegu personalizacji. Można sądzić, że Jan Paweł II przejął tę myśl od Norwida, którego czytał, przeżywał i zinterioryzował bardzo głęboko.

Następna metafora o strategicznym znaczeniu to stwierdzenie, że każdy człowiek jest kapłanem, choć „,bezwiednym / I niedojrzałym” (Sfinks [II], PWsz II, 33). Jest to rewolucyjne, pionierskie, zapowiada ducha Soboru Watykańskiego II. Uwierzyć, że człowiek jest kapłanem, to obalić podział na sacrum i profanum, co ciągle jest gloryfikowane $\mathrm{m}$. in. w dyskursie teologicznym w Polsce, a co jest sprzeczne z Ewangelią, w której czytamy, że zasłona w świątyni wydzielająca Miejsce Najświętsze rozdarła się w chwili śmierci Chrystusa na krzyżu (Mt 27, 51; por Hbr 9,3.12), co zniosło podział w swej istocie pogański na sacrum, związane często z władzą sakralną (i wtedy odrębne od świętości), i profanum,

${ }^{61}$ Zob. https://www.academia.edu/41473184/Ekwiwalencja_w_tradycji_t $\%$ C5\%82umacze\%C5\%84_Biblii_na_j\%C4\%99zyk_polski_a_przesuni\%C $4 \%$ $\% 99$ cia_pola_semantycznego_analiza_hebrajskiego_poj\%C4\%99cia_chesed_\%D7\%97\%D6\%B6\%D7\%A$1 \% \mathrm{D} 6 \% \overline{\mathrm{B}} 6 \% \mathrm{D} 7 \% \overline{0}$ 
które winno być dostępne wszystkim, wezwanym do dojrzewania duchowego. U Norwida obalenie tego podziału jest już wprowadzone implicite właśnie przez metaforę człowieka-kapłana.

Następne strategiczne obrazy symboliczne to krzyż i brama. Krzyż, który należy nosić samemu oznacza prometeizm chrześcijański, który Norwid przejął po Mickiewiczu. U Mickiewicza naród niósł krzyż, ale tu jednostka musi dźwigać krzyż indywidualnie, czyli każdy musi stać się Chrystusem - choć „w różnym stopniu". Jest to zgodne z myślą ezoteryczną XVIII wieku (Louis Claude de Saint Martin), ale i z encykliką Laborem exercens, która ukazuje człowieka jako partnera Boga w odkupywaniu świata. (LE § 27). Narodowy mesjanizm Mickiewicza Norwid przejął i zreinterpretował w duchu mesjanizmu uniwersalistycznego wspólnoty, gdzie praca zbiorowa jest właśnie „bramą”, drogą mesjańską człowieka na ziemi. Budowanie ludzkości to powstawanie z martwych przez pracę. Heroizm charyzmatycznych jednostek został zastąpiony zbiorowym heroizmem ludzkości, która się konstruuje przez pracę. Jest to stwierdzenie zarówno bardzo radykalne, teologicznie aktualne i jednocześnie zbieżne z teoriami hominizacji antropologii współczesnej.

Te cechy nowoczesnego rozumienia wiary przez Norwida uzasadniają stwierdzenie ojca Jacka Salija, znanego teologa, że Norwid jest najwybitniejszym polskim teologiem ${ }^{62}$.

Poprzez swój uniwersalizm etyczny Norwid przynosi odpowiedzi również na współczesny kryzys pojęcia uniwersalizmu racjonalności ukonstytuowany w Oświeceniu. W ostatniej swej książce Zmierzch uniwersalności ${ }^{63}$ Chantal Delsol wydobywa aporie postmodernistycznego rozumienia uniwersalizmu sprowadzonego na Zachodzie do indywidualizmu praw człowieka, i przypomina krytykę Herdera, gdyż jednostka istnieje jedynie w relacji. Współczesne krytyki cywilizacji zachodniej przeciwstawiają indywidualizm zachodni, liberalny i globalny zasadzie zakorzenienia poszczególnych kultur. Humanizm stał się humanitaryzmem: „Można opisać humanitaryzm jako upadłego spadkobiercę humanizmu judeo-chrześcijańskiego, który zastąpił sakralność człowieka przez sakralność świata [...], który zastąpił humanizm stricto sensu przez filantropię; który zastąpił osobę przez jednostkę" ${ }^{\text {"64 }}$. Dalej: „Sakralizacja wolności indywidualnych prowadzi do zniesienia poczucia odpowiedzialności na wszystkich poziomach" ${ }^{65}$. Stąd

\footnotetext{
${ }^{62}$ Por. S. SAwicki, Wartość - sacrum - Norwid 3, Lublin 2017, s. 187.

${ }^{63}$ Ch. Delsol, Le crépuscule de l'universel, Paris 2020.

${ }^{64}$ Tamże, s. 29. Tłum. M. M.

${ }^{65}$ Tamże, s. 75.
} 
waga więzi, jako tworzącej człowieczeństwo ${ }^{66}$. Emancypacja skrajna od relacji jako uwięzienia (,piekło to inni” Satre) - odpowiada godności odpowiedzialności osobistej. „Ograniczam się, bo mam świadomość swej odpowiedzialności” ${ }^{\text {"67 }}$. Racjonalizm boi się transcendencji pionowej religii i dlatego wiąże się z materializmem. Otóż myśl romantyczna, i w znacznej mierze Norwid rozwija perspektywę trascendencji poziomej ${ }^{68}$. Relacje międzyosobowe solidarności, odpowiedzialności, sa formami transcendencji związanej z działaniem ludzkim. Szczególnie rozwinął to Emmanuel Lévinas. Relacje międzyosobowe nie sprowadzają się do prostej subiektywności (jak w racjonalizmie), ale są transcendentne w stosunku do jednostki, którą obejmują i przekraczają.

Metafora Norwidowska człowieka - kapłana drugiego, swego bliźniego oraz mechanizm samostwarzania się przez pracę zbiorową tworzy ludzkość człowieka. W późniejszym tle pojawiają się również metafory Gombrowicza, podjęte przez Miłosza „kościoła ludzkiego”. Norwid wpisuje się również w filozofię dialogu rozwiniętą przez Józefa Tischnera.

Emancypacja jednostki nie powinna przechodzić przez rezygnację z przynależności, co jest wspólne modernizmowi Norwida, Europy środkowej (Kundera, Patoćka); a nawet myśli azjatyckiej.

„Jedynie odpowiedzialność indywidualna (pod warunkiem, że nie będzie stale ośmieszana) może uwolnić społeczeństwo ról (tzn. więzi rzeczywistych i trwałych), jednocześnie zapewniając emancypację” - konkluduje Delsol. „Jedynie Europa oparta na personalizmie a nie na indywidualizmie może uniknąć kryzysu"69.

Pozostały po Norwidzie „skrzydlate słowa” jak ten wiersz o modlitwie, który warto przypomnieć, bo kultury są wyrazem zbiorowego pragnienie - a „twoje pragnienie już jest modlitwą", jak twierdził św. Augustyn ${ }^{70}$ :

Modlitwy idą i wracają - nie ma niewysłuchanej.

(Monolog, PWsz I, 79)

${ }^{66}$ Jak wskazuje Delsol, opozycja więzi i indywidualizmu wywodzi się z przeciwieństwa teorii Vico i Descartesa.

${ }^{67}$ Tamże, s. 361.

${ }^{68}$ Delsol odwołuje się tu do mego hasła w Encyklopedycznym Stowniku pisarzy Europy środkowej $i$ wschodniej od 45 r., w druku, Paris, wyd. R. Laffont. Por też moje Wprowadzenie. Transcendencja pozioma, w: M. Masłowski, Etyka i metafizyka, Warszawa 2011.

${ }^{69}$ Delsol, s. 369-370.

70 Z komentarza św. Augustyna, biskupa, do Psalmów (Ps 37, 13-14), Brewiarz, piątek III tygodnia Adwentu, LG tom I, wydanie II (Pallottinum 2006), s. 275. 
Kultury jako wyraz pragnienia zbiorowego kształtują odpowiedzialność i poczucie przynależności - są odpowiedzią na kryzys indywidualizmu narcystycznego naszej epoki. Norwid ciągle może nam pomóc.

\section{BIBLIOGRAFIA}

Abriszewska P., XIX-wieczna tęsknota za oralnością. Przypadek Norwida, „Studia Norwidiana" 32: 2014, s. 25-40.

Brague R., Europe, la voie romaine, Paris 1992.

Delsol Ch., Le crépuscule de l'universel, Paris 2020.

Feliksiak E., „Norwidowski świat myśli”, w: Polska myśl filozoficzna i społeczna, oprac. A. Walicki, t. I., 1831-1863, Warszawa 1973, s. 545-593.

Feliksiak E., Poezja i myśl. Studia o Norwidzie, Lublin 2001.

Fert J., Norwid poeta dialogu, Wrocław 1982.

GŁowiŃski M., Norwidowska druga osoba, w: Prace wybrane V: Intertekstualność, groteska, parabola., Kraków 2000, s. 340-346.

Halkiewicz-Sojak G., Nawiązane ogniwo. Studia o poezji Cypriana Norwida i jej kontekstach, Toruń 2010.

JAN PAWEe II, Laborem exercens, 1981.

JASTRUN M., Gwiaździsty diament, Warszawa 1971.

LÉvinas E., Całość i nieskończoność. Esej o zewnętrzności, przeł. M. Kowalska, Warszawa 1998.

ŁAPIŃSKi Z., Norwid, Kraków 1971.

Maciejewski J., Cyprian Norwid, Warszawa 1992.

Mitosek Z., Przerwana pieśń. O funkcji podkreśleń w poezji Norwida, „Pamiętnik Literacki” 1986, z. 3.

RoJek P., Liturgia dziejów. Jan Pawet II i polski mesjanizm, Kraków, 2016.

SAWICKI S., Norwida walka z forma, Warszawa 1986.

SAWICKI S., Wartość - sacrum - Norwid, Lublin 1994.

Sawicki S., Wstęp do C. Norwid, Promethidion, Kraków 1997.

SAWICKI, S. Wartość - sacrum - Norwid 3, Lublin 2017.

SŁawiŃsKa I., Sceniczny gest poety, Kraków 1960.

SŁAWIŃsKa I., Reżyserska rȩka Norwida, Kraków 1971.

Stefanowska Z., Strona romantyków. Studia o Norwidzie, Lublin 1993.

ŚwionteK S., Norwidowski teatr świata, Łódź 1983.

Tischner J., Etyka solidarności, Kraków 2000.

Tischner J., Filozofia dramatu, Paris 1998.

Tomkowski J., Wstęp i oprac., w: Polski esej literacki. Antologia, Wrocław 2017.

Woloszyn, B., Norwid ocala. Heroizm, śmierć i zmartwychwstanie w twórczości postromantyka, Kraków 2008. 


\section{MIEJSCE NORWIDA W KULTURZE}

\section{Streszczenie}

Norwida, nawet w obecnej fazie „postnowoczesności”, nie sposób sprowadzić do jednej formuły - jest raczej „konstelacją”, wymagając od czytelników „dyskusji nieustającej” problemów czasu. W centrum uwagi znajduje się człowiek w perspektywie dualistycznej, zmuszającej do poszukiwania syntezy materii z duchem, w perspektywie uniwersalizmu etycznego. Odwołuje się do „kopuły,monologu-nieustannie-się-parabolizujacego”: kultury jako paraboli świata. Oryginalna estetyka „,bieli” odwołuje się jakby do „łagodnego powiewu wiatru" z Biblii świadczącego o przejściu Boga i jest znakiem sprzeciwu wobec romantycznego uwielbienia wulkanu, któremu przeciwstawia wagę pracy. Filozofia ta, rozwinięta przez Brzozowskiego, Tischnera i Jana Pawła II doprowadziła do samoograniczającej się rewolucji „Solidarności” lat 1980-81, i ostatecznie do delegitymizacji i upadku komunizmu; po dwusetletnim panowaniu krwawego mitu rewolucji francuskiej - do przemiany paradygmatu przemian historycznych w świecie.

Norwid opracowywał romantyzm epoki przemysłowej, i przeciwstawiając się mesjanizmowi martyrologicznemu narodu wypracował swoisty „mesjanizm pracy”. Łączył go z wizją Kościoła człowieka, który „przepala glob, Sumieniem”. Kościołowi globu - przeciwstawiał parafiańszczyznȩ, „kościół zmieniony w salonik”. Liczy się człowiek a nie instytucja, dobro a nie Sakrament formalny. Chodzi o zmartwychwstawanie świata, a sztuka jest kościołem pracy. Bliska mu była perspektywa antropocentryczna, gdzie człowiek wezwany jest do „od-poczynania", poczynania na nowo, w drugiej potędze - błędów przeszłości.

Swoim jẹzykiem i stylem Norwid konstruował nową warstwę społeczną - inteligencji (Łapiński) jako rodzaj kopuły narodu, zwornika sumienia, świadomości zbiorowej. Tworząc rodzaj międzyosobowej transcendencji poziomej zarówno wzwyż jak wszerz społeczeństw.

Przeciwieństwem narodu ze swoją kulturą jest „cesarstwo” - źródło niewoli. Zniewalające zwłaszcza Europę Środkowo-Wschodnią. Szczególnie ważne jest starcie się cywilizacji azjatyckiej z chrześcijaństwem, czyli Europą zachodnią, „rzymską”. Poeta stawia jednak Słowianina w opozycji zarówno do Wschodu jak do Zachodu. Pada nacisk na procesualny a nie esencjonalistyczny charakter kultur narodowych.

Problem dialogiczności Norwida czy dominującego monologu dzieli badaczy. Ale Norwid jest w pewnym sensie Mistrzem, nauczycielem, który wciela Innego, wciela Mądrość własnym Głosem i Gestem. Istota Mądrości jest antropocentryczna, gdyż człowiek jest kapłanem, choć „,bezwiednym / I niedojrzałym”, co obala podział na sacrum i profanum. Poprzez swój uniwersalizm etyczny Norwid przynosi odpowiedzi również na Oświeceniowy kryzys pojęcia uniwersalizmu racjonalności. Emancypacja jednostki nie powinna bowiem prowadzić do rezygnacji z przynależności, co jest wspólne modernizmowi Norwida i Europy środkowej (Ch. Delsol). Kultury jako wyraz pragnienia zbiorowego kształtują odpowiedzialność i poczucie przynależności - są też odpowiedzią na kryzys indywidualizmu narcystycznego naszej epoki.

Słowa kluczowe: człowiek, cesarstwo, cywilizacja, dialog, dobro, inteligencja, kopuła, kościół, kultura, nowoczesność, od-poczynanie, Oświecenie, parabola, poezja, praca, Romantyzm, Solidarność, transcendencja pozioma, uniwersalizm etyczny. 


\title{
NORWID'S PLACE IN CULTURE
}

\begin{abstract}
Even in today's "postmodern" world, Norwid cannot be reduced to a single formula. He is rather a "constellation," requiring that readers join the "continual discussion" on issues specific to a given era. His focus is on humanity, which he regards from a dualist perspective that necessitates pursuing a synthesis of matter and spirit under the sign of ethical universalism. Norwid refers to the "cupola of "a monologue-that-keeps-parabolizing-itself" " andregards culture as the parable of the world. His original aesthetics of "whiteness" refers, as it were, to the biblical "gentle gust of wind," which announces God's presence and indicates the rejection of the Romantic veneration for volcanoes, which he contrasts with the importance of work. This kind of philosophy, developed by Brzozowski, Tischner and John Paul II,has led to the selflimiting revolution of Solidarity in the years 1980-81, and ultimately to the de-legitimization and fall of communism; finally, after the bloody myth of the French Revolution reigned for two hundred years, this philosophy altered the paradigm of historical changes around the world.

Norwid elaborated on the industrial-era Romanticism and opposed martyrological messianism, developing the original idea of a "messianism of work,"linking it with a vision of human Church, which "burns through the Globe with conscience."He would contrast the global church with the parochial "church-turned-living-room."Human beings count more than institutions, he argued, just like goodness prevails over formal sacraments. With the ultimate goal defined as the resurrection of the world, art becomes a church of work. Norwid embraced an anthropocentric perspective, in which human beings are called upon "to un-make" [od-poczynać] the mistakes of the past, and thus to begin afresh at a whole new level.

With his language and style Norwid was constructing a new social stratum: intelligentsia (Lapiński), understanding it as the nation's copula, i.e. the unifying force of conscienceand the collective consciousness. It would form an interpersonal, horizontal transcendence spanning the length and breadth of societies.

The opposite of nation and its culture is "empire" - the root of subjugation - which particularly enslaved Central and Eastern Europe. Of special importance is the clash between Asian civilization and the "Roman" one, i.e. Christianity or Western Europe. However, the poet opposes Slavs to both the Westerners and the Easterners, emphasizing the processualand not the essentialistcharacter of national cultures.

The question whether Norwid's work is fundamentally dialogic or monologic in character continues to divide scholars. However, Norwid is in a way a Master or teacherwho embodies the Other and incarnates Wisdom in his Voice and Gesture. The nature of Wisdom is anthropocentric because man is a priest, although "involuntary / And immature," which abolishes the distinction between the sacred and the profane. Through his ethical universalism Norwid provides a solution to the Enlightenment crisis of universal reason. Emancipation of the individual should not entail abandoning a sense of belonging, which is something that Norwid's modernism shares with that of Central Europeans (Ch. Delsol).

Understood as the expression of collective desires, cultures shape responsibility and a sense of belonging, at the same time constituting an answer to the crisis of narcissistic individualism characteristic for our times.
\end{abstract}

Translated by Grzegorz Czemiel 
Key words: humanity, empire, civilization, dialogue, goodness, intelligence, copula, church, culture, modernity, un-making, the Enlightenment, parable, poetry, work, Romanticism, Solidarity, horizontal transcendence, ethical universalism

Micha£ MasŁowsKi - emerytowany profesor Sorbony, wykładowca Uniwersytetu Warszawskiego. Wydał książki o romantyzmie (w tym o Norwidzie), o teatrze i o Europie Środkowej, jak też studia o związkach religii i kultury. Autor około dwustu publikacji, w tym 10 książek po polsku (m. in. Dzieje bohatera (1978); Gest, symbol i rytuały polskiego teatru romantycznego (1998); Zwierciadta Kordiana (2002); Problemy tożsamości (2006); Etyka i metafizyka (2011) Opublikował również szereg studiów o Miłoszu. Redaktor i współredaktor 10 franc. opracowań zbiorowych. Założyciel grup badawczych GREC i CERCLE w Nancy, członek Eur'ORBEM na Sorbonie. Tłumacz na francuski (wraz z J. Donguy) m. in. Dziadów, Kordiana, poezji Miłosza, dramatów Herberta i Różewicza. Członek zagraniczny PAU; odznaczenia polskie i francuskie. 